\title{
Peripheral desmoplastic ameloblastoma: Histopathological and immunohistochemical profile of a case
}

\author{
Ronell Bologna-Molina ${ }^{1}$, Adalberto Mosqueda-Taylor ${ }^{2}$, Paes de Almeida-Oslei ${ }^{3}$, Victor Toral-Rizo ${ }^{3}$, Gui- \\ llermo Martínez-Mata ${ }^{4}$
}

\author{
${ }^{1}$ School of Dentistry, University Juarez of Durango State (UJED), Durango, México \\ ${ }^{2}$ DDS, MSc. Health Care Department, Universidad Autónoma Metropolitana-Xochimilco, México City, Mexico \\ ${ }^{3}$ DDS, PhD, DDS, MSc. Department of Oral Diagnosis, Oral Pathology Section, School of Dentistry of Piracicaba, UNI- \\ CAMP, Piracicaba, São Paulo State, Brazil \\ ${ }^{4}$ DDS, PhD. Oral Pathology Laboratory, School of Dentistry, University of Chihuahua, Chihuahua, Mexico
}

Correspondence:

Paseo de las Galias 169

Colonia Lomas Estrella CP 09890, México DF, México

ronellbologna@gmail.com

Received: 21/10/2009 Accepted: 21/02/2010
Bologna-Molina R, Mosqueda-Taylor A, de Almeida-Oslei P, Toral-Rizo V, Martínez-Mata G. Peripheral desmoplastic ameloblastoma: Histopathological and immunohistochemical profile of a case. Med Oral Patol Oral Cir Bucal. 2010 Nov 1;15 (6):e846-9.

http://www.medicinaoral.com/medoralfree01/v15i6/medoralv15i6p846.pdf

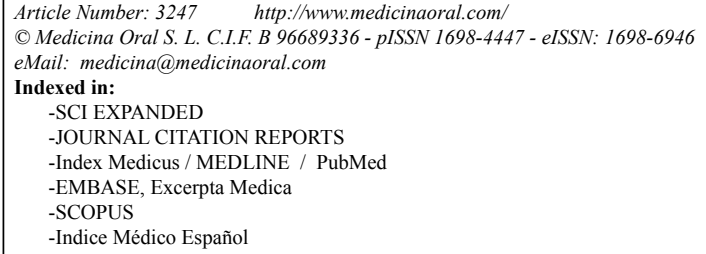

\begin{abstract}
In this study we present a rare case of peripheral desmoplastic ameloblastoma and discuss its clinical features, histopathology, and inmunoshistochemical profile.

This article reports a new case of this unusual neoplasm in a 66 year-old woman in which the main complaint was an asymptomatic swelling located in the right body of mandible. Histopathological findings were similar to the two previously reported cases of this tumor. Positive immunohistochemical stain for laminin V and type IV collagen suggests an inductive effect of the epithelium over the stroma while the low index of p53 protein and Ki-67 expression in epithelium and stromal cells, as well as CD138 uniform positive-stain in epithelial cells, support the benign biological behavior of this lesion. Including this new case, currently there are only three reports of this rare neoplasm. Reports of new cases of peripheral desmoplastic ameloblastoma are necessary for a better understanding of the origin and behavior of this particular subtype of ameloblastoma.
\end{abstract}

Key words: Ameloblastoma, peripheral, desmoplastic, immunohistochemistry.

\section{Introduction}

Peripheral odontogenic tumors (POT) are uncommon lesions, accounting from $1.24 \%$ to $3.4 \%$ of all odontogenic tumors $(1,2)$. According to previous reports, the most frequent $\mathrm{POT}$ are peripheral odontogenic fibroma (POF) and peripheral ameloblastoma (PA) with $40 \%$ and 36\% respectively (1). Contrary to POF its intraosseous counterpart (central odontogenic fibroma) has a higher potential of aggressiveness. On the other hand, it is well recognized the high rate of recurrence observed in central solid types of ameloblastomas, which far exceeds what has been reported for PA. Desmoplastic 
ameloblastoma (DA) was initially defined as a central lesion but recently, two cases of peripheral desmoplastic ameloblastoma (PDA) were reported $(3,4)$. In this study we present an additional case of this unusual neoplasm, and discuss its clinical features, histopathology, and inmunoshistochemical profile.

\section{Case Report}

A 66-year-old woman presented for diagnosis and management of an asymptomatic swelling located in the right body of mandible. Clinical examination revealed an exophytic mass of $2 \mathrm{~cm}$ of diameter, firm to palpation. An excisional biopsy was perfomed and the specimen was sent to histopathological study. No evidence of bone resorption in the area was observed during surgery.

Five $\mu \mathrm{m}$ sections of paraffin-embedded tissue were stained with H\&E stain and immunohistochemistry was performed using avidin-biotin complex technique. (Table 1) shows antibodies, dilutions and sources of antibodies used in this case.

Microscopical examination disclosed a lesion constituted by irregular islands of odontogenic epithelium embedded in a collagenized stroma. Epithelial islands were arranged in nest, narrow cords and more solid sheets of odontogenic epithelium (Fig. 1a). Columnar cells with reverse polarization were not a predominant feature. Some islands were hypercellular with central squamous metaplasia and fusiform cells (Fig. 1b). Multiple microcystic degeneration was observed (Fig. 1a). Stroma was densely collagenized but myxoid changes were found adjacent to epithelial islands.

Table 1. Antibodies, sources, clones and dilutions applied in present case.

\begin{tabular}{|c|c|c|}
\hline Antibody & Source/clone & Dilution \\
\hline Cytokeratin cocktail & Dako $^{\mathrm{TM}}, \mathrm{AE} 1 / \mathrm{AE} 3$ & $1: 500$ \\
\hline CK1 & Novocastra $^{\mathrm{TM}}, 34 \beta \mathrm{B} 4$ & $1: 200$ \\
\hline CK5 & Novocastra ${ }^{\mathrm{TM}}, \mathrm{XM} 26$ & $1: 400$ \\
\hline CK6 & Novocastra $^{\mathrm{TM}}, \mathrm{LHK} 6 \mathrm{~B}$ & $1: 400$ \\
\hline CK8 & Dako $^{\text {TM }}, \mathrm{OV}-\mathrm{TL} 12 / 30$ & $1: 400$ \\
\hline CK10 & Dako $^{\mathrm{TM}}, \mathrm{DE}-\mathrm{K}-10$ & $1: 200$ \\
\hline CK13 & Novocastra $^{\mathrm{TM}}, \mathrm{KS}-1 \mathrm{~A} 3$ & 1.400 \\
\hline CK14 & Novocastra $^{\mathrm{TM}}$, NCL-L-LL002 & $1: 400$ \\
\hline Ck16 & Novocastra $^{\mathrm{TM}}, \mathrm{LL} 025$ & $1: 400$ \\
\hline CK18 & Dako $^{\mathrm{TM}}, \mathrm{DC} 10$ & $1: 400$ \\
\hline CK19 & Dako $^{\mathrm{TM}}, \mathrm{RCK} 108$ & $1: 400$ \\
\hline CK20 & Dako $^{\mathrm{TM}}, \mathrm{K}_{\mathrm{s}} 20.8$ & $1: 200$ \\
\hline Vimentin & Dako $^{\text {TM }}$,Vim 3B4 & $1: 200$ \\
\hline$\alpha \mathrm{SMA}$ & Dako $^{\mathrm{TM}}, 1 \mathrm{~A} 4$ & $1: 400$ \\
\hline p53 & Dako & $1: 200$ \\
\hline $\mathrm{Ki}-67$ & Dako $^{\mathrm{TM}}, \mathrm{MIB}-1$ & $1: 100$ \\
\hline S-100 & Dako $^{\mathrm{TM}}$ & $1: 12,000$ \\
\hline CD138 & Dako $^{\text {TM }}, M I 15$ & $1: 100$ \\
\hline Collagen IV & Dako $^{\mathrm{TM}}, \mathrm{CIV} 22$ & $1: 200$ \\
\hline Laminin & Laminin & $1: 200$ \\
\hline
\end{tabular}
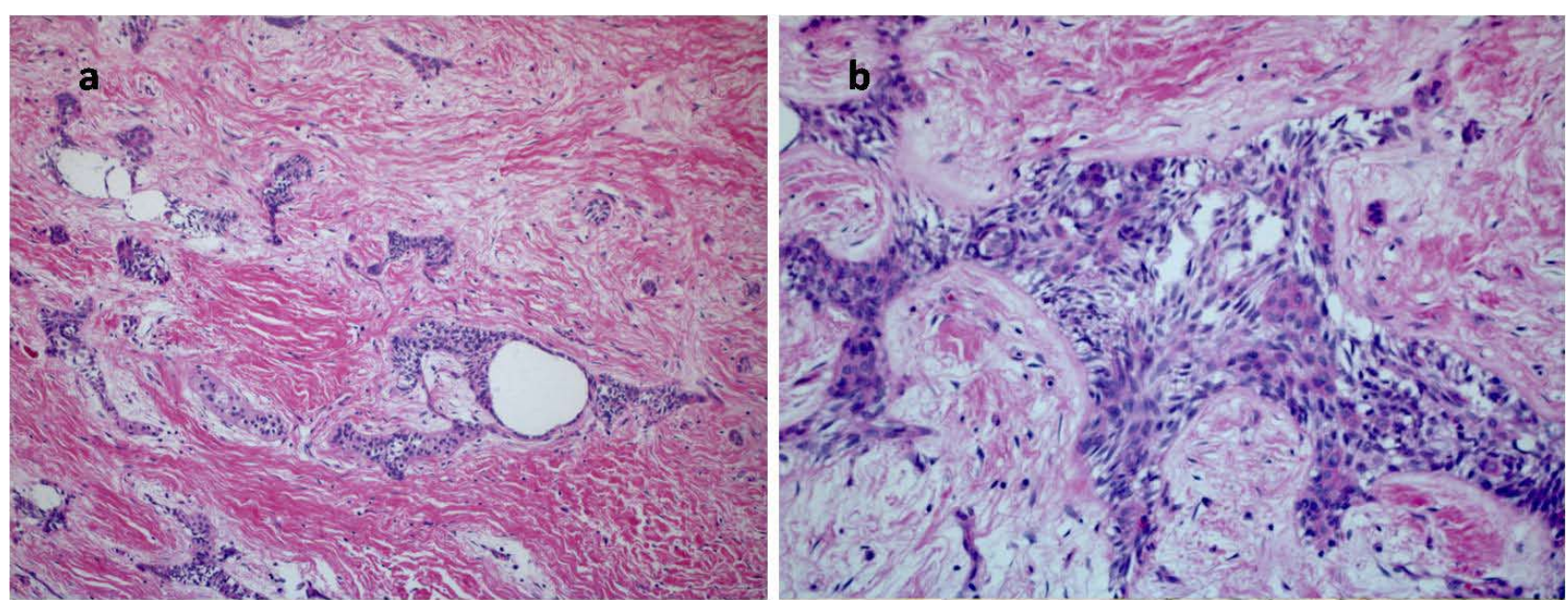

Fig. 1. Photomicrographs showing (a) neoplastic odontogenic epithelium associated to a densely collagenized stroma with multiple microcystic degeneration, (b) note the central squamous metaplasia (H\&E stain, original magnification x200 and x400). 


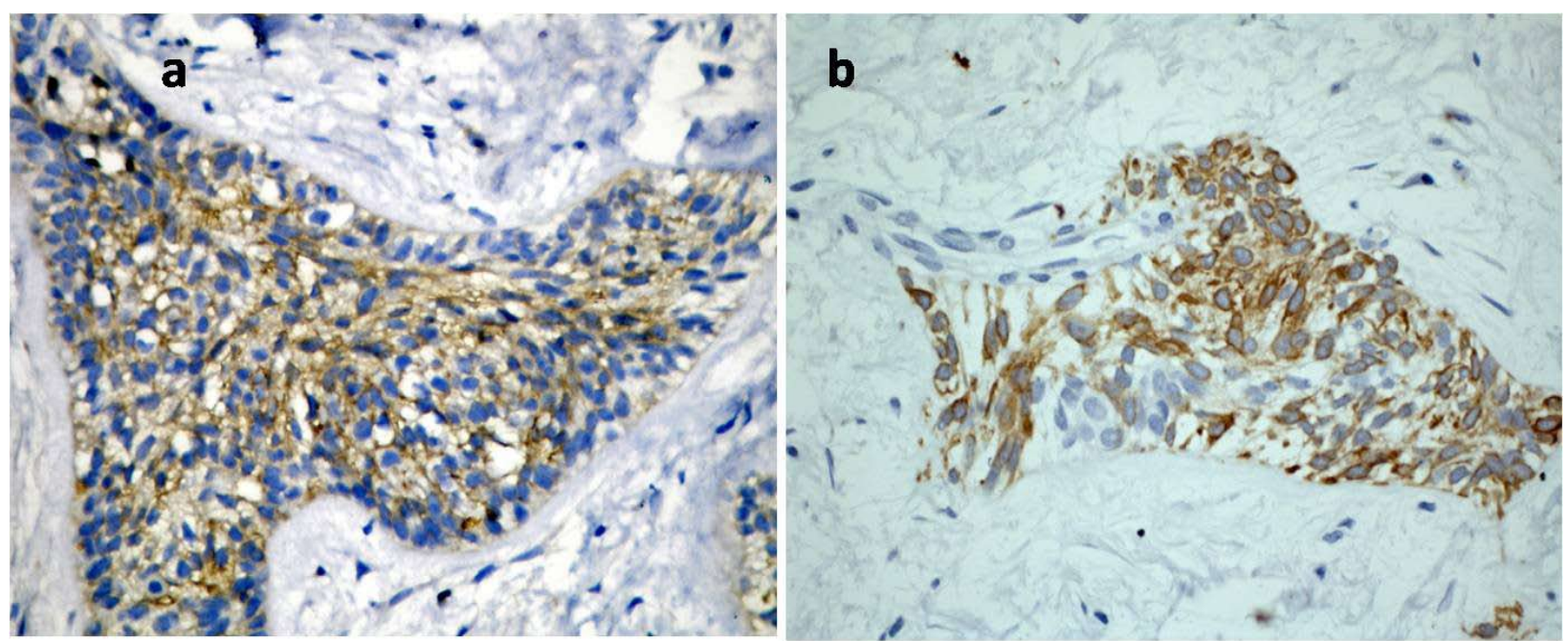

Fig. 2. (a) High expression of syndecan-1 (CD 138) in the ameloblastic epithelium, (b) Positive stain in suprabasal and central epithelial cells for CK14 in PDA (CD138 and CK14, original magnification $\mathrm{x} 400$ ).
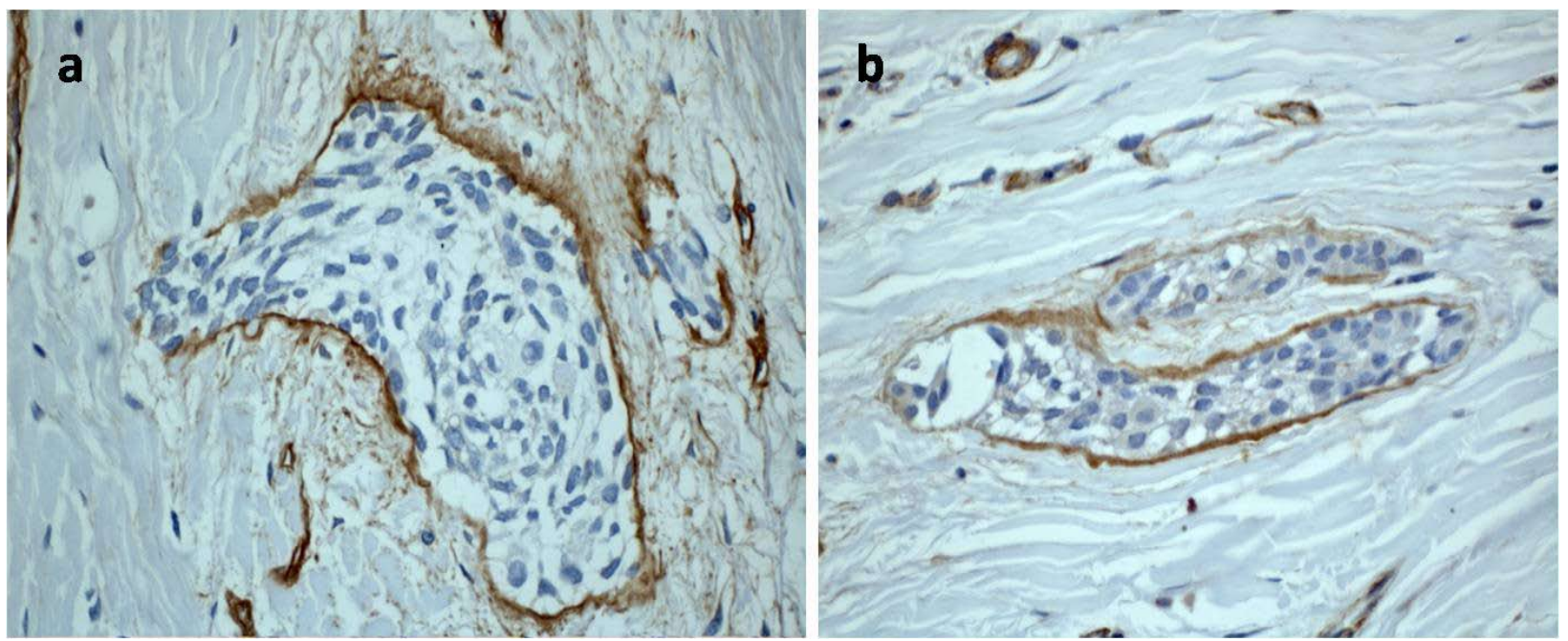

Fig. 3. Expression of Laminin V (a) and type IV Collagen (b) antibodies in basal lamina of PDA (original magnification, $x 400$ ).

Odontogenic epithelial islands were positive for cytokeratin cocktail AE1/AE3, 34ßE12 and CD-138 (syndecan-1) (Fig. 2a). CK5 was positive in basal and suprabasal cells, while some suprabasal and central cells were positive to CK14 (Fig. 2b). Focal stain for CK13 and $\mathrm{S}-100$ protein were observed in squamous central cells. Cytokeratins 1, 6, 8, 10, 16, 18, 19 and 20 were not expressed. Stromal cells were positive for vimentin; antibodies for muscle differentiation (HHF-35 and SMA), Bcl-2 and p21 were also negative. p53 and Ki-67 index were lower than $1 \%$ in epithelial islands and negative in stromal cells. On the other hand, basal membrane of epithelial tissue was intensely positive for laminin $\mathrm{V}$ and type IV collagen (Fig. 3).

After four year of follow-up there are no signs of recurrence.

\section{Discussion}

Since its original description by Eversole et al. (5) DA is considered a rare variant of Central Ameloblastoma (CA). CA represents a frequent odontogenic tumor accounting for $11-60 \%$ off all central odontogenic tumors $(6,7)$ and DA accounts for $5.3 \%$ of all CA (8). To date, 145 cases of DA have been reported in English literature; (9) of these, only two can be considered as peripheral $(3,4)$. It is well known that there are histological and biological behavioral differences among DA and the other types of CA. For example, DA poses a lower recurrence rate as compared to CA. The histological findings in our case are in accordance with previous reports of PDA and DA $(3,10,11)$. Sivapathasundharam et al. (9) suggest that epithelial changes can be related to pres- 
sure of stroma on epithelial tissue or may be associated to changes in maturation of a preexistent CA. However, Kishino et al. (8) and Kawai et al. (12) suggest that DA derives from periodontal ligament, and based their observation in the presence of oxytalan fibers in stroma of this neoplasm. In our case, the lack of continuity of the lesion with surface epithelium and the negative stain of PDA for CK19 in this case is in accordance with the observations of Philipsen et al. (11), who suggest that the origin of this neoplasm can be remnants of dental lamina located in gingival tissues. Immunohistochemical expression of CK5 in basal/suprabasal cells and CK14 in suprabasal/central cells in the present case offer evidence of maturation of the epithelial component; low index of p53 protein and $\mathrm{Ki}-67$ expression in epithelium and stromal cells of PDA, as well as CD138 uniform positive-stain in epithelial cells, support the benign biological behavior of the lesion, as has been reported previously in their intraosseus counterpart. (13) High expression of syndecan-1 in DA could be associated with a better cell-cell and cell-extracellular matrix adhesion in epithelial ameloblastic zones (islands), suggesting a less aggressive and invasive behavior and could explain, to some degree, the unique clinicopathological features of this slow growing lesion, which in turn, may favor the presence of desmoplasia (14).

Another finding of interest in our case was the positive stain for laminin V and type IV collagen, suggesting an inductive effect of the epithelium over the fibrous stroma, which may result in a duplicated basal lamina; this findings support the observations of Lam et al. (15), who found inductive effects expressed in the form of deposits of an acellular eosinophilic matrix associated to epithelial islands in five of eight cases of DA. Periepithelial myxoid changes and the mechanism of desmoplasia are far from being understood (11).

Including this new case, currently there are only three reports of PDA. However, reports of new cases of PDA are necessary for a better understanding of the origin and biological behavior of this particular lesion.

\section{References}

1. Buchner A, Merrell PW, Carpenter WM. Relative frequency of central odontogenic tumors: a study of 1,088 cases from Northern California and comparison to studies from other parts of the world. J Oral Maxillofac Surg. 2006;64:1343-52.

2. Ladeinde AL, Ajayi OF, Ogunlewe MO, Adeyemo WL, Arotiba GT, Bamgbose BO, et al. Odontogenic tumors: a review of 319 cases in a Nigerian teaching hospital. Oral Surg Oral Med Oral Pathol Oral Radiol Endod. 2005;99:191-5.

3. Smullin SE, Faquin W, Susarla SM, Kaban LB. Peripheral desmoplastic ameloblastoma: report of a case and literature review. Oral Surg Oral Med Oral Pathol Oral Radiol Endod. 2008;105:37-40.

4. Curran AE, Byerly PD. Peripheral desmoplastic ameloblastoma: report of a rare case. J Oral Maxillofac Surg. 2008;66:820-5.

5. Eversole LR, Leider AS, Hansen LS. Ameloblastomas with pronounced desmoplasia. J Oral Maxillofac Surg. 1984;42:735-40.

6. Regezi JA, Kerr DA, Courtney RM. Odontogenic tumors: analysis of 706 cases. J Oral Surg. 1978;36:771-8.
7. Odukoya O. Odontogenic tumors: analysis of 289 Nigerian cases. J Oral Pathol Med. 1995;24:454-7.

8. Kishino M, Murakami S, Fukuda Y, Ishida T. Pathology of the desmoplastic ameloblastoma. J Oral Pathol Med. 2001;30:35-40.

9. Sivapathasundharam B, Einstein A, Syed RI. Desmoplastic ameloblastoma in Indians: report of five cases and review of literature. Indian J Dent Res. 2007;18:218-21.

10. Takata T, Miyauchi M, Ogawa I, Kudo Y, Takekoshi T, Zhao $\mathrm{M}$, et al. Immunoexpression of transforming growth factor beta in desmoplastic ameloblastoma. Virchows Arch. 2000;436:319-23.

11. Philipsen HP, Reichart PA, Takata T. Desmoplastic ameloblastoma (including "hybrid" lesion of ameloblastoma). Biological profile based on 100 cases from the literature and own files. Oral Oncol. 2001;37:455-60.

12. Kawai T, Kishino M, Hiranuma H, Sasai T, Ishida T. A unique case of desmoplastic ameloblastoma of the mandible: report of a case and brief review of the English language literature. Oral Surg Oral Med Oral Pathol Oral Radiol Endod. 1999;87:258-63.

13. Bologna-Molina R, Mosqueda-Taylor A, Lopez-Corella E, Almeida OP, Carrasco-Daza D, Garcia-Vazquez F, et al. Syndecan-1 (CD138) and Ki-67 expression in different subtypes of ameloblastomas. Oral Oncol. 2008;44:805-11.

14. Bologna-Molina R, Mosqueda-Taylor A, Lopez-Corella E, de Almeida OP, Carrasco-Daza D, Farfán-Morales JE, et al. Comparative expression of syndecan-1 and $\mathrm{Ki}-67$ in peripheral and desmoplastic ameloblastomas and ameloblastic carcinoma. Pathol Int. 2009;59:229-33.

15. Lam KY, Chan AC, Wu PC, Chau KY, Tideman H, Wei W. Desmoplastic variant of ameloblastoma in Chinese patients. Br J Oral Maxillofac Surg. 1998;36:129-34. 